\title{
Anthony Löwstedt \\ Rights versus Diversity? The Accelerated Extinction of Languages and Cultures as an Aspect of Current Globalization Trends
}

\begin{abstract}
:
This paper starts from the assumption that linguistic diversity, and more generally, cultural diversity, are intrinsically good. I will look at their opposites, linguistic and cultural poverty, and the current tendencies towards the latter within the globalization process. I will also briefly explore the relationship between human rights and cultural diversity, which may be viewed as somewhat problematic, but the emphasis will be on what I consider the essential aspect of that relationship, namely, the mutually reinforcing relationship between rights and diversity, and between their opposites, human rights violations and cultural uniformity (cultural poverty). In this context, the issue of legislative protection and promotion of cultural diversity will be investigated from a global perspective. Finally, I wish to assess the roles of Africa and of Africanicity with regard to these issues.
\end{abstract}

\section{Agenda}

The Impending Disaster 203

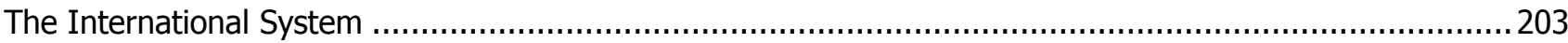

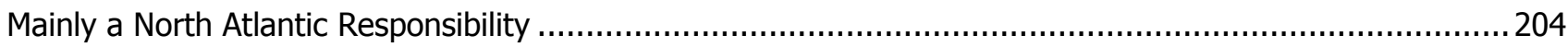

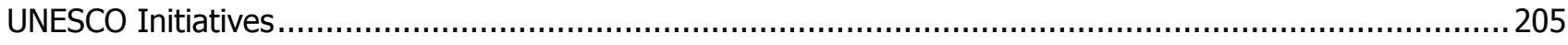

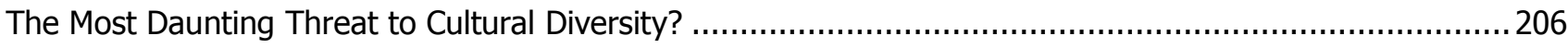

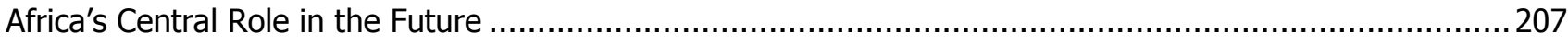

\section{Author:}

Dr. Anthony Löwstedt:

- Department of Media Communications, Webster University, Berchtoldgasse 1, A-1220 Vienna, Austria

- $\quad \widetilde{2}$ +43-1-587 $6206, \square$ lowstedt@webster.edu 


\section{The Impending Disaster}

The forms in which information comes and goes is crucial, but they are sometimes overlooked or underestimated, in information ethics as elsewhere. Language is still the most conspicuous form of information and we tend to rush to use English although there might be other possibilities. Even philosophers and information theorists are usually more concerned with the subject matter of the language used, i.e. the meanings of the words and sentences, than with their linguistic forms. We therefore tend to see language as a means more than as an end. Yet, linguistic diversity is central to cultural diversity as well as to information ethics, and it is suffering appalling defeats today.

Because we think so much in words, the loss of languages limits the possibilities of human thought, knowledge, and communication. Indigenous knowledge is being lost as a result of the death of languages. More than half of the world's languages, perhaps even as much as $95 \%$, of the world's languages are threatened with extinction by the end of this century. ${ }^{1}$

This high rate is perhaps unprecedented in human history. We and our children will therefore almost certainly live through the era during which most languages will die. And Africa is the continent that is

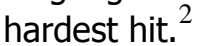

Analysts mainly blame the spread of commercialism and consumerism, and, secondly, the rapid global spread of English, as the main factors behind this, perhaps the greatest threat ever not just to linguistic diversity but also to cultural diversity. But there are many additional factors, such as US- and UKdriven cultural imperialism, discriminatory shortsighted policies aimed to support members of linguistic minorities ${ }^{3}$, urbanization, monopolistic,

1 United Nations Environment Programme: Press Release: Globalization Threat to World's Cultural, Linguistic and Biological Diversity; SkutnabbKangas, Tove: Human Rights and Language Policy in Education

${ }^{2}$ Foundation for Endangered Languages: Manifesto

${ }^{3}$ One example would be offering schooling in English to indigenous Canadian non-English-speaking Inuit children, officially so that they can compete in the wider labor market. Another example would oligopolistic and expansionist developments in communications business and technology. Other factors include sharp population increases and territorial expansions of already large human populations, the spread of French, Arabic, and Chinese, or the spread of missionary religions. ${ }^{4}$

\section{The International System}

The concept of 'linguistic genocide' was defined separately from physical genocide and roundly condemned by the United Nations in the final draft of the 1948 Convention on the Prevention and Punishment of the Crime of Genocide. But then the article on linguistic genocide was voted down by only 16 members, most of them powerful north Atlantic states. $^{5}$

Beyond outright genocide, it is likely that some other sort of oppression, whether classism or racism, is at work when linguistic diversity suffers. These may be the kinds of situations in which an indigenous language is not targeted, but it ends up as 'collateral damage'. Today, in so-called 'postcolonial' Africa, around $90 \%$ of Africa's intellectual output is produced in European languages. Not even a single treaty between Europe and Africa exists in any African language. In more than half of Africa's countries the official language is different from the

be all-Bulgarian schooling for Rroma children in Bulgaria. If anything, this policy is evidence of the decision-makers' failure to see the forest due to the overabundance of trees! These children will be behind their native English-speaking peers from the very start and will often never catch up. Most likely, they will be put in classes for students with learning disabilities and fall behind further. The solution is of course to offer schooling in both languages, but the moral dilemma, between the individual human right to choose education (for oneself or for one's child) and the duty to preserve and promote cultural diversity, will remain, at least on the individual and familial levels.

4 Hamelink, Cees: Confronting Cultural Rights; Skutnabb-Kangas, Tove: Linguistic Genocide in Education - Worldwide Diversity or Human Rights?

${ }^{5}$ Capotorti, Francesco: Study of the Rights of Persons Belonging to Ethnic, Religious and Linguistic Minorities. 37; Skutnabb-Kangas Linguistic Genocide in Education - Worldwide Diversity or Human Rights? 
language most used, and only 13 per cent of African children are receiving primary education in their mother tongue. $^{6}$

Africa's and much of the rest of the developing world's countries' answer so far has been to put the West to shame. India has 16 official languages. South Africa, a country with some 40 million inhabitants, embraced a total of 11 official languages after liberation from apartheid in 1994. In contrast, the European Union, an association of 27 economically well-off countries (most of whom joined after 1994), has only 26 official languages, less than one per country on average. The USA, the home of 300 million people, also has only one de facto official language. Canada, the second largest country in the world, has only two. And all of these North Americans only use European languages officially. On the other hand, an estimated $50 \%$ of Native American languages, spoken in the continent before the invasion by Europeans, have died out or been killed off. Due to long-lasting centralized states and brutal histories of war and conquests, within their own continents as well as outside them, western Europe and North America today have the lowest rates of linguistic diversity in the world. Europe is by far the poorest continent with regard to linguistic diversity. Only $3 \%$ of the world's languages are spoken there. The percentage of languages spoken in other continents is the following: $15 \%$ in the Americas, $30 \%$ in Africa, $32 \%$ in Asia and $20 \%$ in the Pacific region. ${ }^{7}$ Yet, nobody seems surprised today when someone says that "Europe is rich" or "Africa is poor".

The concept of globalization is often taken to involve progress beyond the nation-state, since transnational corporations now act regardless of state borders, but in fact the division of the world into a worldwide system of sovereign nation-states is a pre-requisite for globalization. The essential characteristics of this system is that the world is divided into around 200 sovereign nation-states typically covering huge tracts of territory and containing millions of people. A global market incorporates (or is superimposed upon) all of these states, but there is no global state to regulate the global market.

${ }^{6}$ wa Thiong'o, Ngugi: A People without Memory Are in Danger of Losing Their Soul; Skutnabb-Kangas, Tove: Human Rights and Language Policy in Education

${ }^{7}$ Cru, Josep \& Ponce, Amélie: Exercise File: Linguistic Diversity in the World
Since there are 5,000-7,000 languages in the world today and up to $95 \%$ of them are threatened by extinction within this century, we can see where we are rapidly heading if current trends prevail: towards a maximum of around 200 languages worldwide.

In order to save cultural diversity, we must realize that the global system of nation-states, both before and during globalization, is a huge disaster, leading us towards unprecedented global cultural impoverishment, and probably also to massive and otherwise avoidable human rights violations. The bankruptcy of the nation-state is not, however, a complete cultural bankruptcy. Obviously, nationality is part of cultural identity for billions of people. It is the sovereignty that is the problem. Africa should not consist of 54 countries, but rather of 2,500. That is the number of languages spoken on the continent at present. But the Africans were not allowed to draw their own borders. Not even the people of Europe were asked to draw their own borders. The European elites did it, all over the world. It is a political, democratic, and moral bankruptcy. And it is a cultural disaster.

There are precedents, though rather in the realm of religion than language. For example, the introduction of Christianity as the state religion of the late Roman Empire meant the persecution and deaths of the ancient Egyptian, Greek, Roman, and other religions. It probably resulted directly in hundreds of thousands of killings. Perhaps it also brought a fresh sense of identity to many people who had found less and less meaning in the old religions. Nevertheless, from the points of view of cultural diversity as well as of human rights, tolerance would have been far better.

\section{Mainly a North Atlantic Responsibility}

The north Atlantic elites do not seem to like to be told or reminded of these events or of their responsibility for it, but this is exactly what they must be told and reminded of if cultural and linguistic diversity are going to have any chance of escaping the most pessimistic prognoses. The abysmal record of the north Atlantic with regard to cultural and linguistic diversity, at home and abroad, must become a prioritized message of South Africa's and the rest of the world's ambassadors to the Western countries and to powerful globalized north Atlantic institutions such as the UN, the WTO, the IMF and the World Bank. Here, for once, South Africa is able to argue 
from a position of strength, and, more importantly, from a moral high ground.

Not only knowledge is lost with the extinction of a language. Literature (oral as well as written) is also irreversibly lost, so is wisdom, and individual human lives, too. As Native Americans, Swedish Samiti, and Australian Aborigines lose their languages, knowledge, religions, and myths, they lose their bearings and place in the world, as well. Alcohol and drug abuse, high suicide and crime rates are almost inevitable consequences. Some try to fight back against the immediate threat, against the culture that is replacing theirs, for instance the militant Basques in Spain, and therefore lives are being lost outside the threatened ethnic groups, as well.

Cultural and linguistic diversity must, in my opinion, not be justified. Although they can be a means of survival (e.g. the use of Amazon herbal medicines to prevent cancer) or means of well-being (e.g. Hoodia, the plant used by the San to lose sensations of hunger, which can also be used by obese people to lose weight), they should also be seen as intrinsically good. Cultural diversity is not just good as a means, it is also an end in itself. It does not merely make the world a more interesting, a more beautiful, and a more fun place. It is good in and by itself.

Does this mean that, say, 6 billion different languages would be better than 3 billion languages for today's world? Not at all. Long-term viability and effects, such as the inevitable, constant mergers and fragmentations of languages must be taken into consideration. I am not extending an invitation to the Tower of Babel. People can learn additional languages more easily if they know their own well.

The current world language status of English enables communication between more people than ever before. (Unfortunately it seems so far mainly to consist of one-way communication to more people than ever before.) Yet the Jamaican and West African varieties of English are beginning to manifest characteristics of becoming more than just dialects, namely new languages. I believe Africans, at home and in the Diaspora, can teach many westerners that it is normal for one person to speak many languages. Cultural diversity does not end even with the individual human being, because each single one of us is a carrier of many cultures as well as a potential of new cultures.

The average number of native speakers of a language today is $5,000-6,000$. The largest number is 850 million (Mandarin Chinese). Only 80 languages are spoken by more than 10 million people. Such a high number is only achieved by means of imperialist expansion. ${ }^{8}$

A better distribution would be fewer megalanguages, fewer native speakers of the 80 megalanguages, and more substantial numbers of native speakers of threatened languages. Moreover, special efforts should be made to save language groups and isolates, e.g. the entire Khoisan language phylum of southern Africa, or the indigenous Japanese Ainu language, which has no known relatives and is spoken by only around 150 people today.

\section{UNESCO Initiatives}

Along with biodiversity, cultural diversity should perhaps take on and challenge 'human rights' as a rallying point for the $21^{\text {st }}$ century. On the occasion of adopting UNESCO's 2001 Declaration on Cultural Diversity, the organization's Director-General expressed the hope that it would "one day acquire as much force as the Universal Declaration of Human Rights". ${ }^{9}$ Yet, most of the time, diversity does not contradict human rights. Rather, they reinforce each other. But so do their opposites.

Of all countries in the world, only the USA and Israel voted against UNESCO's legally more binding Convention on the Protection and Promotion of the Diversity of Cultural Expressions in 2005. The USA routinely vetoes international condemnation of Israel's violations of human rights. The US vetoes in favour of Israel in the UN Security Council since 1982 actually outnumber all other vetoes by all other permanent Security Council members combined. And so perhaps Israel feels obliged to assist the USA when the USA wants backing for less cultural diversity, and for more homogenized cultural products and markets at home and abroad. But the proliferation of overwhelmingly pro-Israeli cultural products of Hollywood and the other US media products (especially news products) dealing, if ever so slightly, with the Middle East, are of course also in Israel's interest. ${ }^{10}$

${ }^{8}$ Cru, Josep \& Ponce, Amélie: Exercise File: Linguistic Diversity in the World

9 UNESCO: Press Release, General Conference Adopts Universal Declaration on Cultural Diversity

${ }^{10}$ Unescopress: General Conference Adopts Convention on the Protection and Promotion of the Diver- 
Even if cultural diversity has a somewhat tense relationship with individual rights, under certain circumstances, they are in my opinion not antithetical concepts. I believe this is best seen by looking at the powers that regularly violate human rights and counteract cultural diversity, such as the USA and Israel.

The fate of global cultural diversity has ended up hostage to power politics and to insatiably profithungry media corporations and their advertiser clients. That is not acceptable. The opposite of cultural diversity is not unity. It is cultural poverty. But not only linguistic and cultural diversity are held hostage, human rights are, too.

In official comments on the devastating vote against the USA and Israel (148-2, with four countries abstaining), the USA said the UNESCO treaty is "deeply flawed," protectionist, and a threat to freedom of expression. ${ }^{11}$ Freedom of expression is a basic human right (UN Universal Declaration of Human Rights, §19), and it appears far-fetched indeed that US cultural products could help to further freedom of expression more when the world is already full of them. It is my view a much graver threat to freedom of expression that so many cultural products need an unofficial go-ahead from the West nowadays in order to reach any mass audiences at all.

One rather covert apologist for the Americans, Joost Pauwelyn, suggests there are two ways of "how best to sustain minority cultures - through public institutions, subsidies and screen quotas, as the [UNESCO] convention implies, or rather by vigorous antitrust rules and the free flow of ideas, as its critics retort". ${ }^{12}$ But he does not mention the obvious facts that vigorous antitrust rules for the global market (which is the mass media market of today) can only work through a global authority, i.e. a

sity of Cultural Expressions; Mearsheimer, John J. \& Walt, Stephen M.: The Israel Lobby and U.S. Foreign Policy; Löwstedt, Anthony: Apartheid Ancient, Past and Present: Systematic and Gross Human Rights Violations in Graeco-Roman Egypt, South Africa, and Israel/Palestine

11 Pauwelyn, Joost: The UNESCO Convention on Cultural Diversity, and the WTO: Diversity in International Law-Making?

12 Pauwelyn, Joost: The UNESCO Convention on Cultural Diversity, and the WTO: Diversity in International Law-Making? world state, and that the USA is doing everything it can to prevent the appearance of an authoritative regulator of the global market, i.e. a world state. ${ }^{13}$ The US refusal to recognize the International Criminal Court, international conventions against torture, biological weapons, landmines, child labour, the Kyoto Protocol against climate change, and the UN Human Rights Council, are evidence of US opposition to any kind of global democracy or even pluralist global regulation.

\section{The Most Daunting Threat to Cultural Diversity?}

I agree with Pauwelyn that vigorous antitrust rules and the free flow of ideas could do much to sustain minority cultures, but the USA is too formidable an obstacle to even entertain the idea of ever implementing such rules, let alone executive powers that are not controlled by the USA itself.

Anthony Giddens and Will Hutton once wrote that a global antitrust regime (an 'International Competition Authority') is necessary to save democracy, and that the single most important business to regulate in this regard is the mass media, because the increasingly oligopolistic transnational mass media giants, whether they are Murdoch's News Corporation, Berlusconi's Fininvest, or the AmericanJapanese Time Warner Sony network, are hollowing out democracy worldwide. ${ }^{14}$ But this call for sanity has never been echoed by any US or European official. Herein lies the possibly most daunting threat to cultural diversity.

The US charge of protectionism against the UNESCO treaty is also suspect. Granted that WTO rules aim to overthrow protectionism, and that the EU member countries all voted for the UNESCO Convention for mainly selfish reasons such as saving their own film industries, it should be remembered that the WTO is an American invention and an arm of US power, and that cultural products cannot be treated like washing powder. ${ }^{15}$ Unfortunately, the economies of scale that now govern the global cultural market can currently only be limited by state protection. State protection in the UNESCO context is not

\footnotetext{
13 Monbiot: George: How to Stop America

${ }^{14}$ Giddens, Anthony \& Hutton, Will: Fighting Back

15 Monbiot: George: How to Stop America
} 
'protectionism', it is a desperate, last resort to enable the possibility of survival.

Therefore, UNESCO's cultural diversity convention is the next best thing. Only a fully democratic world state with the authority and enforcement mechanisms necessary to implement vigorous global antitrust policies would be better. And the official US objections to the UNESCO treaty are nowhere near constructive criticism. From the point of view of cultural diversity, they are in fact destructive, and otherwise little more than self-serving hypocrisy.

\section{Africa's Central Role in the Future}

In my own view, some of the most important things that Africa can teach the rest of the world today is that cultural and biodiversity must prevail. And this can be done by practice as well as by teaching.

Another important, related thing that Africa can teach us is the unity of humankind: ethically, historically, socially, culturally, and even genetically. In my opinion, Africa has suffered and is still suffering greater ethical wrongs than any other continent. I am referring to the racist Transatlantic and Arab systems of slavery, as well as to colonialism, apartheid, and neo-colonialism, and more. Yet, still, there is astoundingly little vengefulness or even bitterness in African behaviour towards Europeans, Westerners, or Arabs. Historically, Africa is the source of civilization and through the ancient Egyptian civilization it is one of the most important roots (next to Sumer) of ancient Mediterranean and Levantine civilizations, including the three great monotheistic religions and the ancient Greek as well as the Roman civilizations, whose latter-day offshoots today dominate the world. In terms of human genetic variation, the rest of us humans all fit inside a mere parenthesis within the great spectrum of African genes. Africanicity is a necessary complement to cultural diversity. As opposed to the uniformities and cultural poverty resulting from or imposed by global anarchic capitalism and by north Atlantic political, military and economic power, Africanicity has always been and still is a unity which enables and promotes cultural diversity. I am not saying it is the only one. Humanity or, what I think is a better concept, Ubuntu, is another.

And if democracy is to progress at all, then there must be at least a vision of the global democracy to which I was referring above, in which the humble African peasant woman has a vote equal to that of the president of the USA, or to the European Com- mission president, or to the chairman of the board of News Corporation International.

Finally, it appears to me that Information Ethics, whether African or not, must not merely be viewed with individual rights (or duties) in mind. Yes, human rights are good and crucial to human welfare, but if only understood as the rights of individuals, they will not be conducive to cultural diversity, nor to biodiversity, and therefore, not to Humanity or Ubuntu. Solidarity, tolerance, and social rights are lacking in today's world, and at least this may be shown to the impoverished parts of the world by Africa, not least with regard to its still wonderful cultural diversity.

\section{References}

Capotorti, Francesco: Study of the Rights of Persons Belonging to Ethnic, Religious and Linguistic Minorities, New York: United Nations, 1979

Cru, Josep \& Ponce, Amélie: Exercise File: Linguistic Diversity in the World, Linguapax, no date, http://www.linguapax.org/pdf/FileDiscoveryENG. pdf

Foundation for Endangered Languages: Manifesto, no date, http://www.ogmios.org/manifesto.htm

Giddens, Anthony \& Hutton, Will: Fighting Back, in Hutton, Will \& Giddens, Anthony (eds.): On the Edge: Living with Global Capitalism, London: Jonathan Cape, 2000: 213-223

Hamelink, Cees: Confronting Cultural Rights, Media Development, No. 4, 2001, World Association for Christian Communication, http://www.wacc.org.uk/wacc/publications/medi a development/archive/2001 4/confronting cult ural rights

Löwstedt, Anthony: Apartheid - Ancient, Past and Present: Systematic and Gross Human Rights Violations in Graeco-Roman Egypt, South Africa, and Israel/Palestine, Wien: Gesellschaft für Phänomenologie und kritische Anthropologie, $3^{\text {rd }}$ edition, 2007, http://www.dada.at/gems/gesellschaft/Aparthei d.pdf

Mearsheimer, John J. \& Walt, Stephen M.: The Israel Lobby and U.S. Foreign Policy, London Review of Books, Vol. 28, No. 6 (March 23, 2006), http://www./rb.c0.uk/v28/n06/mear01 .html

Monbiot: George: How to Stop America, New Statesman, June 9, 2003, http://www.monbiot.com/archives/2003/06/09/ how-to-stop-america/ 
Pauwelyn, Joost: The UNESCO Convention on Cultural Diversity, and the WTO: Diversity in International Law-Making? The American Society of International Law, November 15, 2005, http://www.asil.org/insights/2005/11/insights05 1115.html

Skutnabb-Kangas, Tove: Linguistic Genocide in Education - Worldwide Diversity or Human Rights?, Mahwah, New Jersey: Lawrence Erlbaum, 2000, Outline of the Book: http://akira.ruc.dk/ tovesk/newbook.htm

Skutnabb-Kangas, Tove: Human Rights and Language Policy in Education, Article for Encyclopedia of Language and Education, Volume 1, Political Issues, edited by Stephen May \& Nancy Hornberger (in press)

wa Thiong'o, Ngugi: A People without Memory Are in Danger of Losing Their Soul, $4^{\text {th }}$ Steve Biko Memorial Lecture, New African, December 2003: 50-55

UNESCO: Press Release, General Conference Adopts Universal Declaration on Cultural Diversity, November 2, 2001, http://www. unesco.org/confgen/press rel/0211 01 clt diversity.shtml

Unescopress: General Conference Adopts Convention on the Protection and Promotion of the Diversity of Cultural Expressions, October 20, 2005, Press Release No2005-128, http://portal. unesco.org/en/ev.phpURL ID $=30298 \& U R L D O=D O$ TOPIC\&URL SEC TION=201.htmI

UNHCHR Submission on Linguistic Rights in Education, Submitted May 15, 1998, to the XVI Session of the Working Group on Indigenous Populations of the United Nations Centre for Human Rights, Geneva, July 27-31, 1998, UN Document E/CN.4/Sub.2/AC.4/1998/2

United Nations Environment Programme: Press Release: Globalization Threat to World's Cultural, Linguistic and Biological Diversity, February 8, 2001 http://www. unep.org/Documents. multilingual/D efault.asp?DocumentID $=192 \&$ ArticleID $=2765$ 